\title{
Moritz Schwarz
}

\section{Interview with Leon Krier}

Entrevista a Léon Krier

\section{Entrevista com Leon Krier}

(Originally published in Junge Freiheit, Berlin, 21 August 2020)

\begin{abstract}
Resumen $\mid$ Resumo
The conservative weekly Berlin Newspaper Junge Freiheit was intrigued by Krier's pun in a 1993 Die Welt article. Following the then official cancellation of the Berlin Castle reconstruction project, Krier had quipped that Germany had to continue doing architectural penance for the Nazi sins. The immense popular success of reconstructions currently being completed in Berlin, Potsdam, Dresden, Frankfurt, despite regular political and professional sabotage, mark indeed a historic break with modernist post war architectural austerity. They are clarion calls for a radical change in established architectural policies and education.
\end{abstract}

Al semanario conservador de Berlín Junge Freiheit le intrigaba la broma de Krier que aparecía en un artículo publicado en 1993 por Die Welt. Tras la cancelación oficial del proyecto de reconstrucción del Palacio Real de Berlín, Krier dijo en broma que Alemania tenía que seguir haciendo penitencia arquitectónica por los pecados nazis. El enorme éxito popular de las reconstrucciones que actualmente se están acabando en Berlín, Potsdam, Dresde y Frankfurt, a pesar del continuo sabotaje político y profesional, supone, efectivamente, una ruptura histórica con la austeridad del "modernismo" arquitectónico de posguerra. Son un llamamiento para un cambio radical en la educación y en las políticas arquitectónicas establecidas.

O jornal semanal conservador de Berlim Junge Freiheit ficou intrigado com o trocadilho de Krier num artigo do Die Welt de 1993. Na sequência do então cancelamento oficial do projecto de reconstrução do Castelo de Berlim, Krier gracejou ao afirmar que a Alemanha tinha de continuar a fazer penitência arquitectónica pelos pecados nazis. $\mathrm{O}$ imenso sucesso popular das reconstruções actualmente em curso em Berlim, Potsdam, Dresden, e Frankfurt, apesar da frequente sabotagem política e profissional, marca de facto uma ruptura histórica com a austeridade arquitectónica modernista do pós-guerra. São apelos públicos claros a uma mudança radical nas vigentes políticas arquitectónicas e na educação em arquitectura. 


\section{Moritz Schwarz: Mr. Krier, is architecture in Germany really inspired by an impetus for} penance and punishment after 1945?

Léon Krier: When in 1993 Wilhelm von Boddien's initiative to rebuild the Royal Castle of Berlin was stalled sine die by Mayor Eberhard Diepgen and Building Minister Irmgard Schwätzer, I wrote, amused and desperate, for an article in Die Welt, that a faithful reconstruction of Schlüter's Schloss design would indeed have meant a national disgrace for Berlin, and yes, even for Germany. Because with this single, most prominent gesture, forty years of modernist anti-reconstruction philosophy, its moral pretensions and presumed legitimacy would have been radically called into question.

\section{M.S.: How is that?}

L.K.: Well, according to the reigning modernist credo, buildings by the great Hans Scharoun, Mies van der Rohe and Le Corbusier may be restored and rebuilt in their original state in a conservative manner, and even those that were never built may be erected posthumously, but Schlüter, oh no, ladies and gentlemen, that would go too far! After all, Germany sinned collectively and should continue to collectively practice architectural penance. The raw ugliness of East and West Central Berlin is not a sign of intellectual ineptitude. No, on the contrary, it is a symbol, hardened in building material, of the highest intellectual effort, of critical penitential abnegation! Our pluralism proves every day that we are capable and ready for anything - but rebuilding Schlüter, no, for God's sake! Thank God, Herr von Boddien's persistence won after all. His erection in 1994 of the arresting castle dummy in the original size won the hearts decisively.

M.S.: In the meantime, "traditional" construction and reconstruction are taking place again: in addition to Berlin, the palaces in Potsdam or Hanover, the Frauenkirche, the Adlon Hotel, the Frankfurt Römer etc. Hasn't the motive of penance and punishment long since been overcome?

L.K.: The reconstructions of historical buildings in Germany from Dresden to Potsdam were all realized through private initiatives by specially motivated citizens, always against the architectural establishment and administrations! Things have not changed today, whether it is the case of the Frankfurt Schauspielhaus or the Potsdam Garrison Church. Only the half-timbered houses on Frankfurt's Römerberg were hammered through by the mayor himself against the competition decision. In 1987 the architect in charge, Ernst Schirmacher, who had made a name for himself in the traditional reconstruction of the city of Limburg, was awarded the "Prix de la Reconstruction de la Ville Européenne”.

Up until the Second World War, rulers throughout all ages, ideologies and regimes backed up their legitimacy by commissioning beautiful buildings and works of art, magnificent ceremonies, displaying good manners, using fine language and clothing. Hitler, Stalin and Roosevelt marked a preliminary end of this tradition. Since then, the representatives of the state, culture, trade and industry of all countries - with the exception of the Prince of Wales and the King of Bhutan - see themselves as soldiers in the battle for securing the supremacy of Modernism in all fields.

\section{M.S.: And are they in contradiction to the democratic majority?}

L.K.: The broad and worldwide approval by citizens for "historical", i.e. traditional reconstructions - whether in Williamsburg, Ise, Moscow, Paris or Nuremberg, for example, is undeniable. The official narrative, according to which only Modernism is democratic and modern, is increasingly threadbare. My friend Peter Eisenman, who designed the Berlin Holocaust memorial, asserted in a public debate with me that Classicism was poisoned and rendered obsolete for all eternity through its abuse by the Nazi regime. I replied that he could just as easily say that about the German language, the autobahns, the mass media, industrial production, about mass society in general! And so, my conviction is exactly the opposite: namely, that the traditional architectural styles practised under Hitler, Mussolini or Stalin survived their totalitarian abuse unscathed and can be valued and used safely by democratic societies. That is exactly what applies to magnificent buildings of long-gone despotic regimes and tyrants. 
Since 1945, Modernism has practically established a one-party system in matters of architecture, town planning, education, administration and industry. Those who don't obey the dictum are denigrated as reactionaries/fascists and kept away from major public work contracts and professorships. On the contrary, reputable Nazi architects such as Otto Apel, Ernst Neufert or Wilhelm Kreis were acceptable after the war, because they switched overnight to Modernism. Any deviation from the modernist diktat is first ignored, then labeled as extremist and therefore condemned, slandered, and ostracised.

\section{M.S.: You differentiate between Modernism and Modernity. What is the difference?}

L.K.: The term modernity has a chronological meaning, relating to time, to the contemporary period. Modernism, on the other hand, is an ideology. The confusion of the terms stems from the claim of Modernism to embody the only legitimate form of modernity, namely in the form of the "Modern Movement".

\section{M.S.: How did the architecture scene react to your thesis of the impetus for penance and punishment?}

L.K.: When I published the volume Architecture. 1932-1942 about Albert Speer at the Archives d'Architecture Moderne in Brussels, the magazine Bauwelt published a special issue in 1987 with the title: "The great Speer- celebration of Léon Krier. From Classicism to genocide“. I was not even given the opportunity to correct the bad translation or to respond to the untenable allegations.

\section{M.S.: Conversely, how much encouragement and support do you receive for your criticism?}

L.K.: Prof Max Bächer, then President of the BDA, the German Architects Association, was the only colleague who publicly defended my theses. Amazingly, Frei Otto backed me, but only privately. Otherwise, I became fair game on the architecture scene. In 1985, Peter Eisenman held a conference entitled "Open Letter to Leon Krier" at the Architectural Association in London, the UK's oldest independent architecture school, where I had taught previously, calling me an anti-Semite and misogynist. At the time I was commissioned to design the Sainsbury's wing of the National Gallery in London. As a result of the smear campaign, David Alford, of Yorke, Rosenberg, Mardall Architects, who was entrusted with the execution of my project, handed in his resignation. Jacob Rothschild, my client, who knew that the defamations were phony, then hired Harry Cobb, I.M.Pei's partner, to build my project. Cobb agreed but I was psychologically so damaged by the trumped-up allegations that I resigned from the job and went into hiding at the American Academy in Rome for several months.

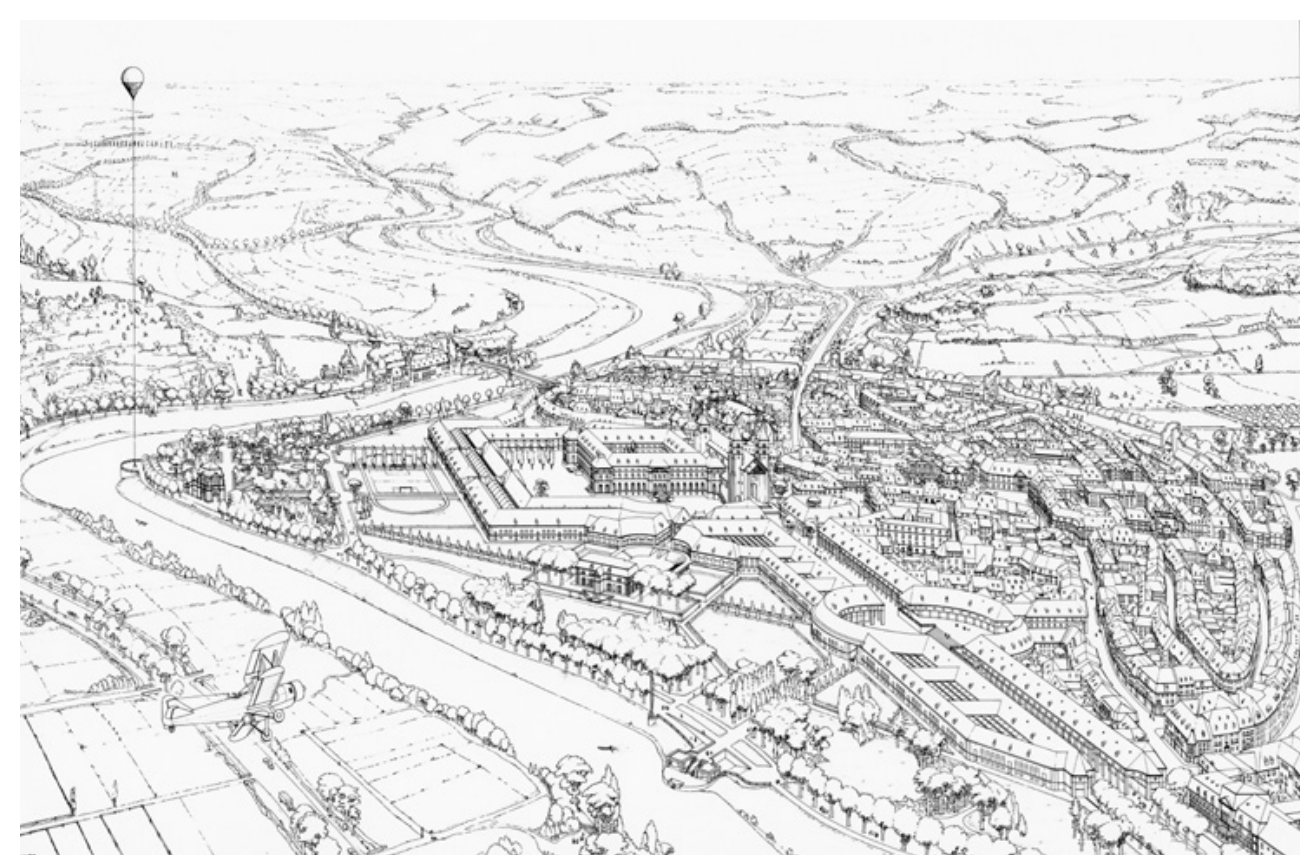




\section{M.S.: What did that mean for your career?}

L.K.: In the subsequent 35 years, I only ever had one job in Germany: for the art dealer couple Hans-Jürgen and Helga Müller. The "Atlantis" project was duly shredded by the German press in over a hundred polemical articles. During the 1992 Kassel Documenta the project became victim of an arson attack. It seems to have been completely forgotten in Germany that democracy is based on pluralism and oppositional debate! I only survived the storm because I had an international reputation and operated on a modest état, independent and without employees. With an office and depending on local networks and clients you cannot survive such a professional assassination. When the architectural magazine $A R C H+$ started the initiative "Against Reconstructions, Architectural Populism and Modernism-Hostility" in support of Professor Stephan Trüby's "Reconstruction Watch", I wrote to him several times proposing a public debate in a major German medium. After almost two years of silence we are now in contact and I am hopeful that such a discussion can take place.

M.S.: Does "punishment through architecture" have any psychological effect on Germans at all, or does it not affect most people who are focused on coping with everyday life?

L.K.: Beauty attracts and ugliness repels. Most people retain, despite daily ideological brainwashing, a sense of the beautiful as well as the ugly. You don't need long explanations to realize that you prefer Rothenburg ob der Tauber to the Märkisches Viertel, a West Berlin high-rise public housing ghetto. Ugly architecture is a contradictio in terminis, because architecture is a building "art". Modernist buildings, however, are strictly speaking not architecture, but artless assemblages of synthetic building material. Residential zones, business zones, cultural zones, and industrial zones are merely monothematic storage areas for short lived utility buildings. Unrelated to place, climate, soil, altitude, i.e. to the defining conditions of all traditional buildings. The "Modern Movement" does not build cities, villages or towns in the conventional sense. It is no fun for anyone to design, build, use and live in, or- with the exception of a dozen prestigious buildings by Mies, Le Corbusier and Axel Schultes - to visit them. Normal people put up with them with a sigh: "It's not beautiful but functional". It is a tough piece of mental work for artistically gifted people, teachers and apprentices, to suppress their artistic leanings. Yet it is the order of the day, since 1945 and without sound justification, for architects, entrepreneurs, craftsmen, administrators and last but not least for the citizenry. The disenchanted world that arises from the collective asceticism merely provides spaces for a joyless and disenchanted life. Modern society is lectured daily that there is no alternative to "modern" urban planning and architecture. It is getting harder every day to keep up the lie. The success of reconstructed buildings, such as the Dresden Frauenkirche and the Neumarkt area are, in my understanding, first tentative steps in Germany towards a global reform of the built environment.

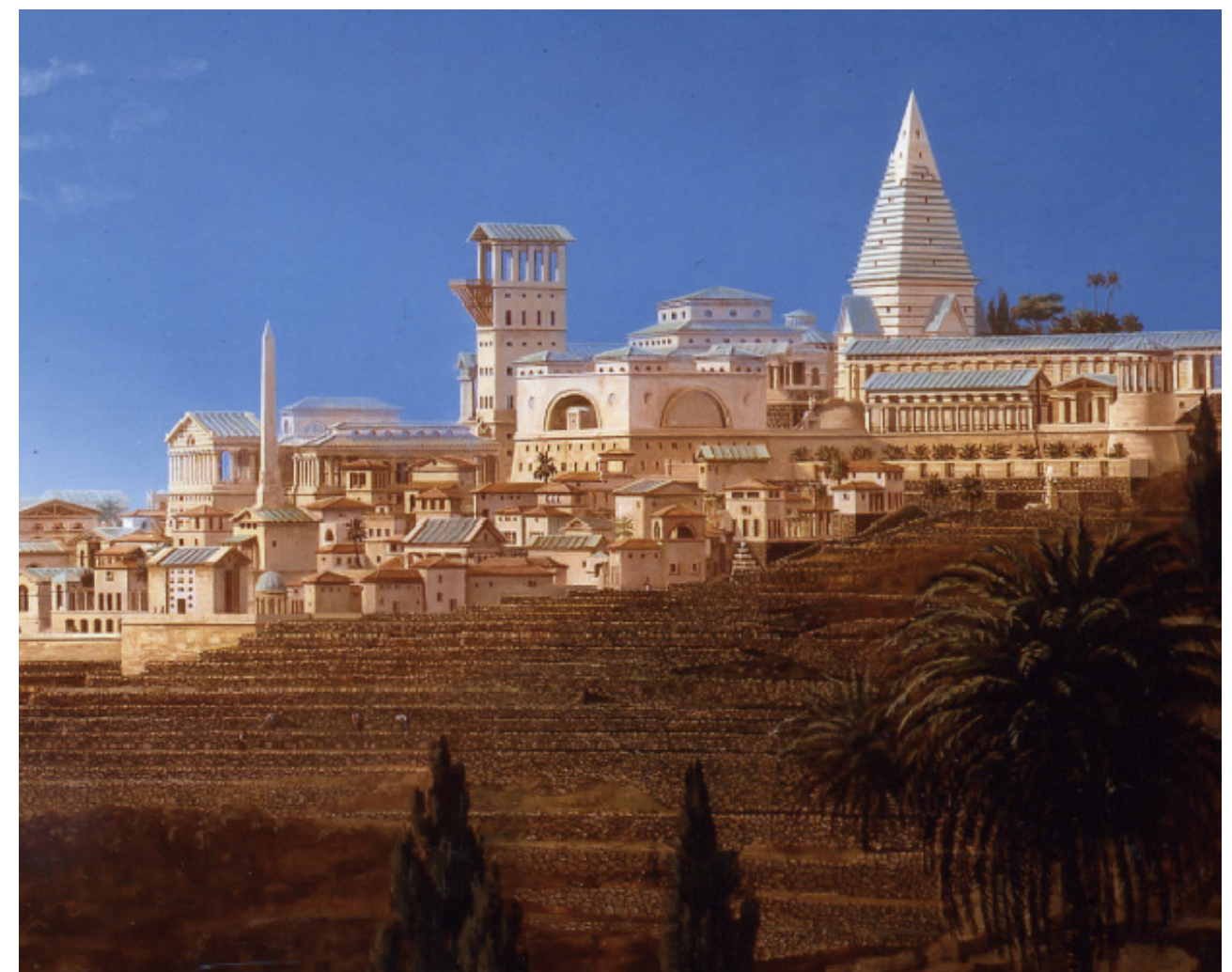




\section{面县C \\ "ZEITGEIST" (L.K.05) "ORTGEIST"}
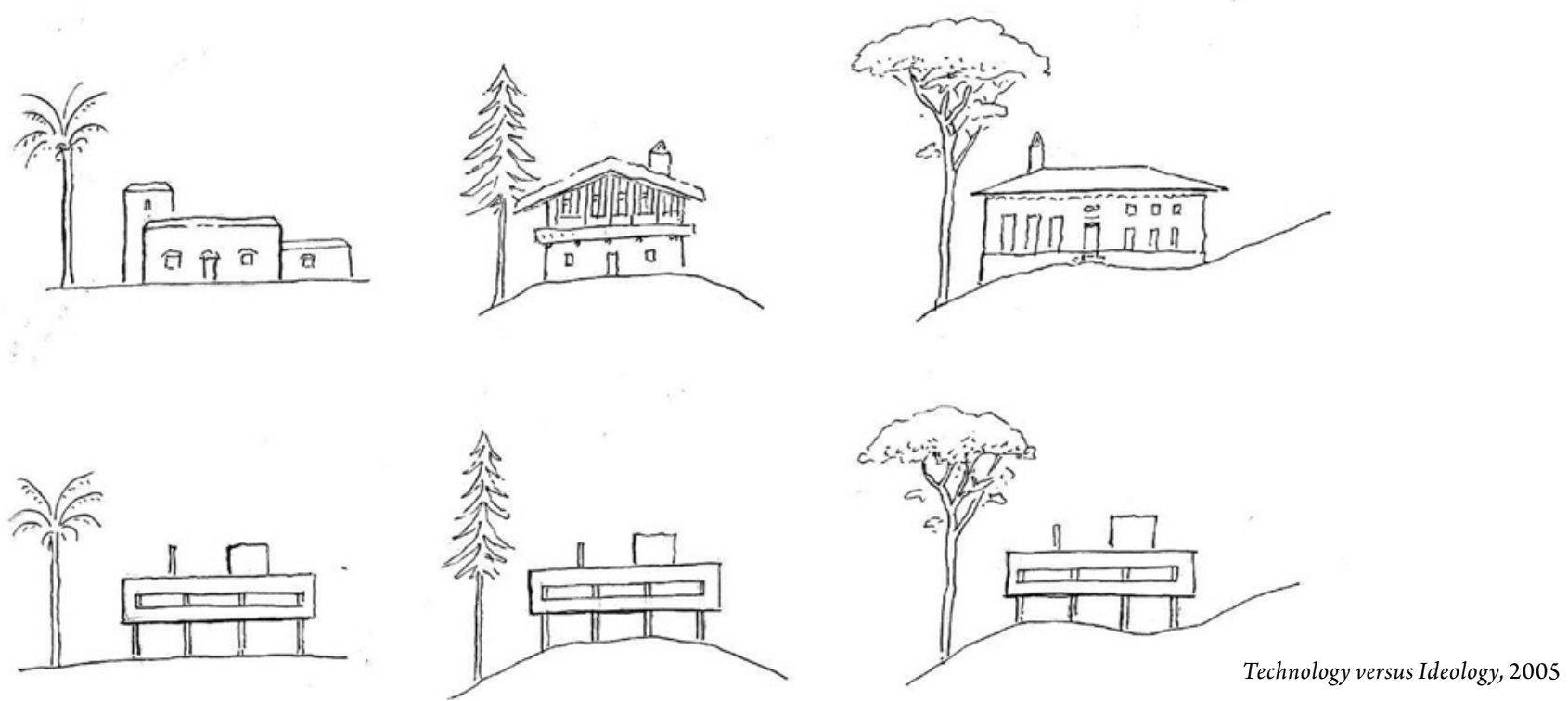

M.S.: But what about the counter-argument that "ugly" building has nothing to do with penance and punishment, but that it is only felt that way by people without education and taste? In fact, modern architectural styles are progressive, creative, bold and artistic. While traditional "beautiful" building is simply lagging behind, unimaginative and without artistic or creative value?

L.K.: A fundamental mistake of "Modernism" is to sell itself as a global alternative to traditional architecture - as progress that frees mankind from outdated ballast. So far, however, it has been little more than an artless construction technique that can operate solely with synthetic materials. It is experienced worldwide that even the most "creative" modernist artists fail to create an acceptable village or cityscape. Whether Walter Gropius, Le Corbusier or Oscar Niemeyer, they are only capable of a form of architectural stutter, lacking the grammatical, syntactic, and orthographic organizations of complex building languages and design principles.

\section{M.S.: Why?}

L.K.: Modernism in architecture is only possible with synthetic building materials and joining techniques. Furthermore, without air conditioning systems, modernist building are unusable in the Sahara or in Siberia. The broad use of synthetic materials and industrial processes is only viable in conditions of affordable fossil and atomic energy. Without their broad availability there will be no "Modernist" building or urbanism.

\section{M.S.: Doesn't that also apply in principle to traditional architecture?}

L.K.: Traditional architecture is not a building style, but first and foremost a building technology operating with natural local building materials and with human hand- and mind-resources to realize stable and beautiful building forms. Architecture is the translation of these forms and materials into an artistic, codified building language. In order to understand the superiority of traditional architecture, let us make the following contrasting assumptions: First, imagine that through an inexplicable incident and suddenly our entire architectural heritage up to the Second World War disappeared from the surface of the earth: all historical buildings, hamlets, villages and towns. Then imagine that the same thing happens to all "modern" buildings and settlements built after 1945, for equally inexplicable reasons. And now ask yourself: what loss could you emotionally endure? And which kind of world do you want to call your home? 


\section{M.S.: Well, "emotionally endure" most probably the disappearance of modern buildings ...}

L.K.: Exactly. And why does the traditional appeal to you more deeply than the products which represent our time? The beauty of architecture is just as timeless as the beauty of nature. In general, people don't care how old or historical a building is, or who the architect or client was. Even a godless philistine will not amble by the reconstructed Frauenkirche in Dresden without being moved. The beauty of architecture and places unites people, classes and religions. A Christian can spontaneously admire beautiful Islamic mosques and a Muslim can delight in the beauty of cathedrals. The servant admired the beauty of the castle and the prince takes pleasure in the beauty of the stable. The anarchist can admire the works of totalitarian regimes. Beauty is not political, it is simply used or abused politically. Only hypocrites deny that evidence.

M.S.: But modern building expresses today's modern world, so another counter-argument. "Beautiful" building, on the other hand, is self-delusional with which one would like to make the world attractive when it really isn't. That is inauthentic, apolitical and a kind of cultural Disneyland. Aren't these convincing arguments? And don't these arguments show that it is about art and not about penance and punishment?

L.K.: I repeat what I tried to make clear earlier: Modernity is not a question of style. Everything that is built today is modern according to the dictionary. The philosophical crime of "modernism" is the ideological recoding of the word modernity and the parallel "historicization" of forms and techniques of traditional and classical building. That manipulation is as scandalously stupid as claiming the wheel to be a historical artefact and ipso facto obsolete. Traditional architecture and traditional town planning are first and foremost technologies to create beautiful buildings and places with local resources, both materially and spiritually. My statement that Germans should forever repent architecturally for a collective sin committed by their forebears, was a bad joke to wake people from a 3-generation long tumble.

\section{M.S.: How now, everything just a trick, not meant seriously?}

L.K.: The "repentance" argument was meant as a provocation, so that people no longer let themselves to be aesthetically enslaved. The liberation from that oppression happened through reconstruction initiatives all around Germany and now in Paris, where President Macron has given up the silly idea of putting a "creative symbol of modernity" on Notre Dame. Even President Trump has a "Presidential edict" still to be signed, according to which the Classicism should be the preferred style for Federal Buildings.

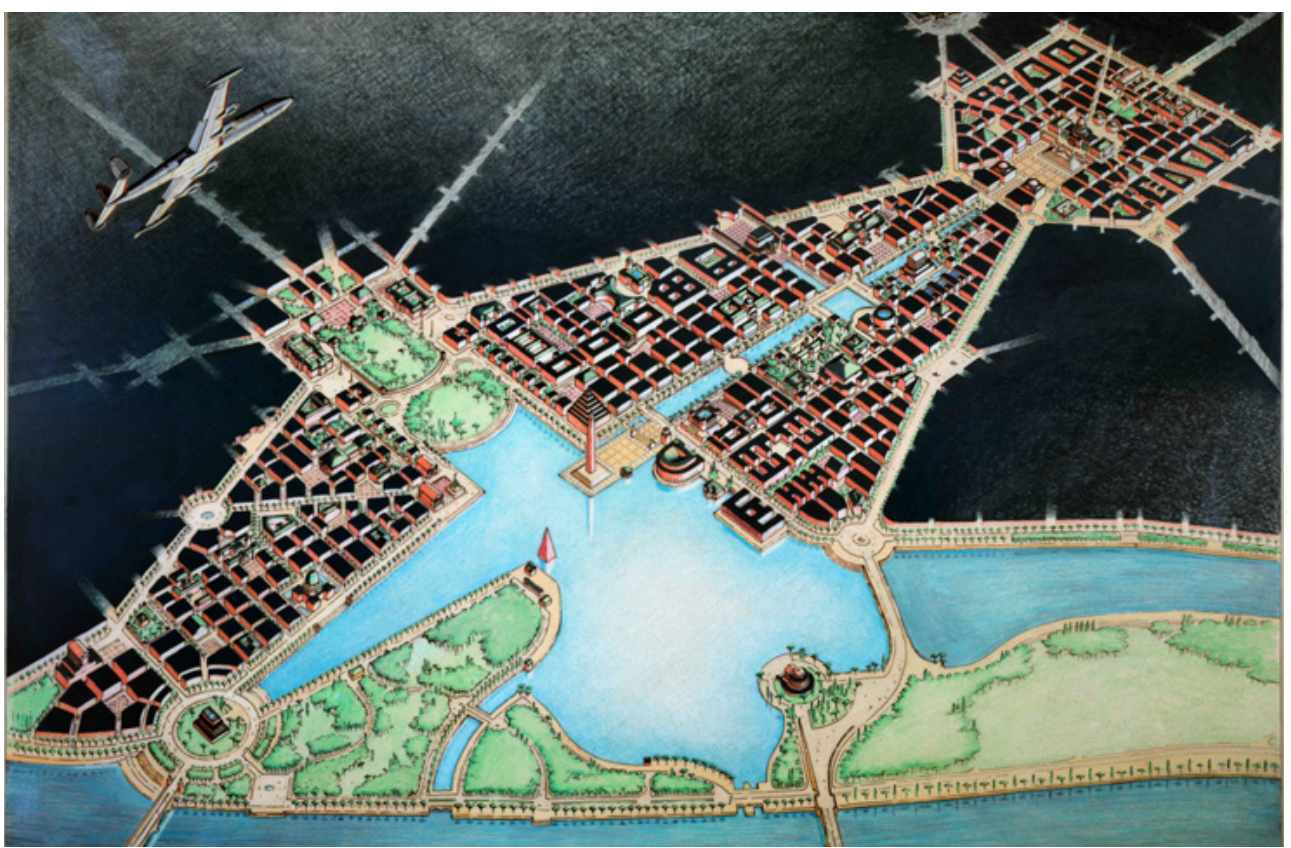


M.S.: You say that the majority of citizens are resigned to the way things are built today, but they do not welcome it. How is that actually possible? We don't live in absolutism or in an authoritarian state, but in a democracy in which the citizens are actually self-determined.

L.K.: The fact that we live in a sham democracy has been demonstrated by the lack of choice in matters of architecture in East and West since 1945. Not the citizens but the architects alone dictated the architecture of large building contracts from the state and subsidized construction companies. Traditional building trades survived on a back burner only through small businesses in the country and especially in the mountains. Without the massive pressure from citizens' initiatives and the impressive commitment of individual personalities such as Wilhelm von Boddien in Berlin, Torsten Kulke in Dresden or Jürgen Aha in Frankfurt, not a single reconstruction project in Germany, so valued by the vast majority, would have succeeded! The majority of the citizens' votes in favour of the reconstruction of the Dessau Palace Square was recently thwarted by the administration using the quorum trick. So, when it comes to culture and architecture, we actually live in a perfidious form of absolutism. Our museums of modern art, our squares, our banks, churches, town halls, schools, administrative buildings, right up to the Bayreuth proscenium are, without exception, packed with artless junk and cheap provocations.

\section{M.S.: But why do the citizens put up with it?}

L.K.: Why are the lambs silent? There are many and long answers to this. But even if they have been silenced, their feelings for the beautiful, the good and the meaningful are not dead. People are being persuaded that no viable alternative is possible in our financial and production system. That however is a lie! Because even within the present form of capitalism there exist many countermodels to the modernist wasteland.

\section{M.S.: For example?}

L.K.: From 1963, François Spoerry built the enchanting marina town of Port Grimaud near St. Tropez. It was realised within the construction costs of French social housing and through local small business owners. However, only a few politicians have recognized the importance of this successstory. His experiment has revolutionary cultural and economic relevance. The residential complex Las Lomas de Marbella Club in Malaga, Andalusia, by Donald Gray was built at the same time. It is a masterpiece of urban architecture and urbanism that belies the dominant modernist narrative which continues to devastate Spanish cities and landscapes. Shortly before his death at the age of

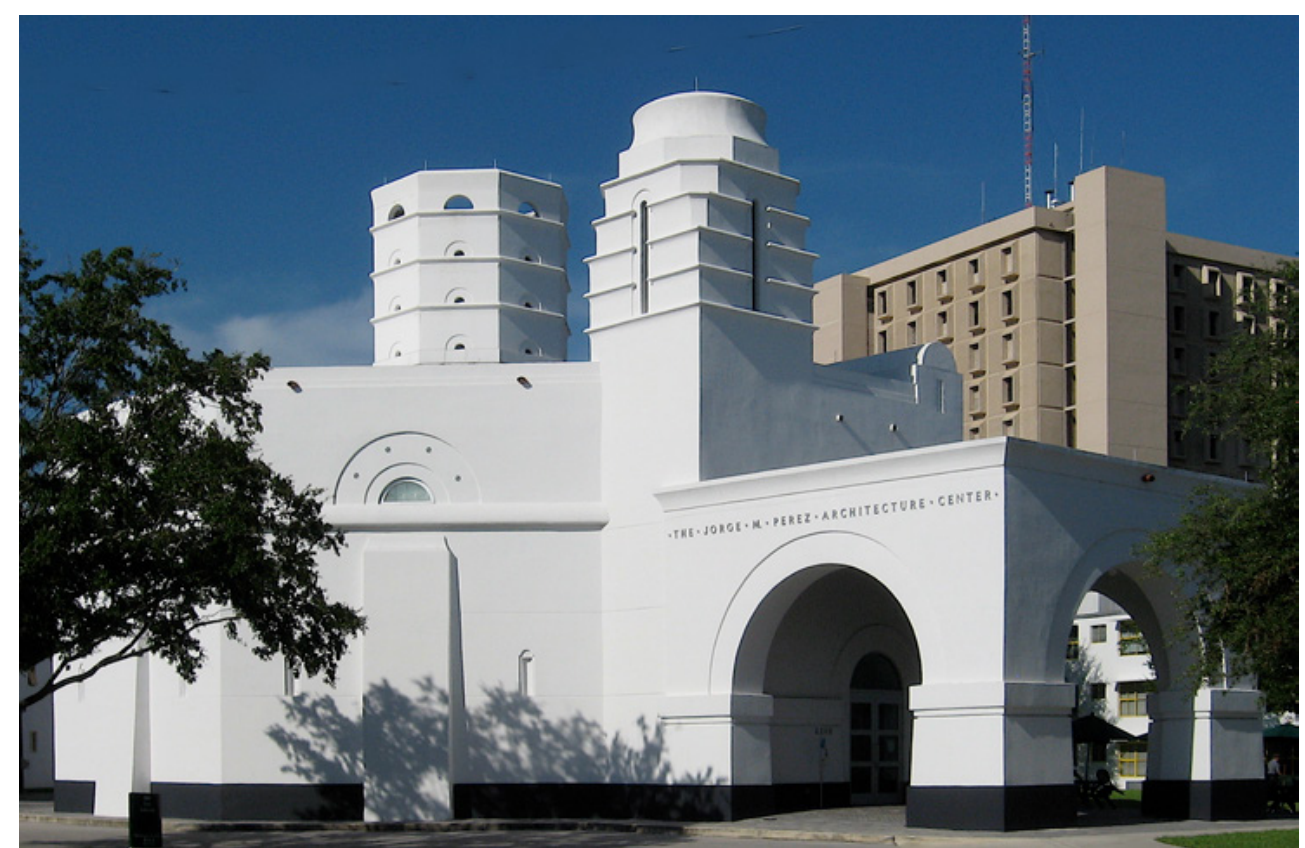

Jorge M. Perez Architecture Center at the University of Miami School of Architecture in Miami, 2003 


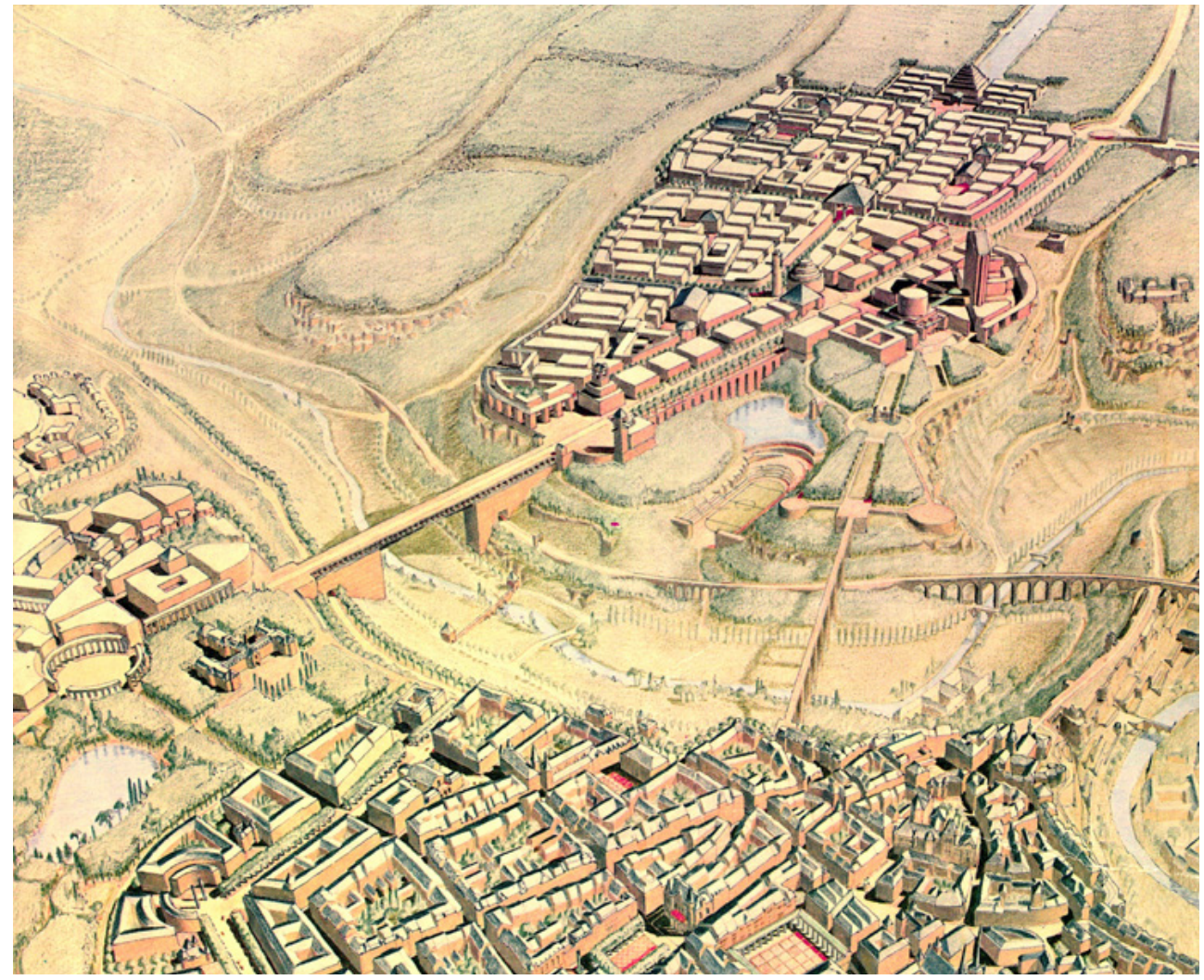

eighty, Gray won his first professional recognition with the prestigious Premio Rafael Manzano for New Traditional Architecture. He wasn't an architect by training but an English teacher in love with Andalusia.

M.S.: Are there really any signs that the era of modern architecture is coming to an end? I am not referring to individual projects that have been pushed through against the architectural mainstream, to which you referred earlier. But a broad change, a structural change in the situation?

L.K.: There are no signs of a broader turnaround - because Modernism keeps politics, administrations and education in a stranglehold. Most of the architects who practice classical architecture and traditional building around the world today have acquired the necessary knowledge through selfeducation! From the classicists practicing in Germany today, such as the brothers Jürgen and Rüdiger Patschke, Sebastian Treese, Christoph Sattler, Paul Kahlfeld or Rob Krier, only Helmut Peuker learned from a classical master, namely Bruno Schindler senior, who until the eighties taught traditional building techniques as a solitaire at the TH in Aachen. In Germany, classicists have no access to public commissions. Yet recently in the competition for the design of Königsufer and Neustädter Markt in Dresden in 2019, two classical proposals won the two first prizes for the first time. The exceptional outcome was only possible because the "Gesellschaft Historischer Neumarkt Dresden" and the citizens were actively involved in the preparation and decision. The administration is now generating pressure to cancel the democratic competition decision. In France there are larger urban projects such as Val D’Europe or Port Royal en Provence, and also model renovation projects for deteriorated "Cités" such as Plessis-Robinson, by French architects Marc and Nada Breitman and the office of the aforementioned Spoerry. In Holland Rob Krier realized several remarkable new traditional towns such as Brandevoort. If they are not systematically ignored, these immensely popular and economically successful projects are routinely decried by the news media as "Disneyland".

M.S.: But what should beautiful and at the same time also contemporary, artistically sophisticated architecture look like, beyond the mere reproduction of classic forms of past architectural styles? 


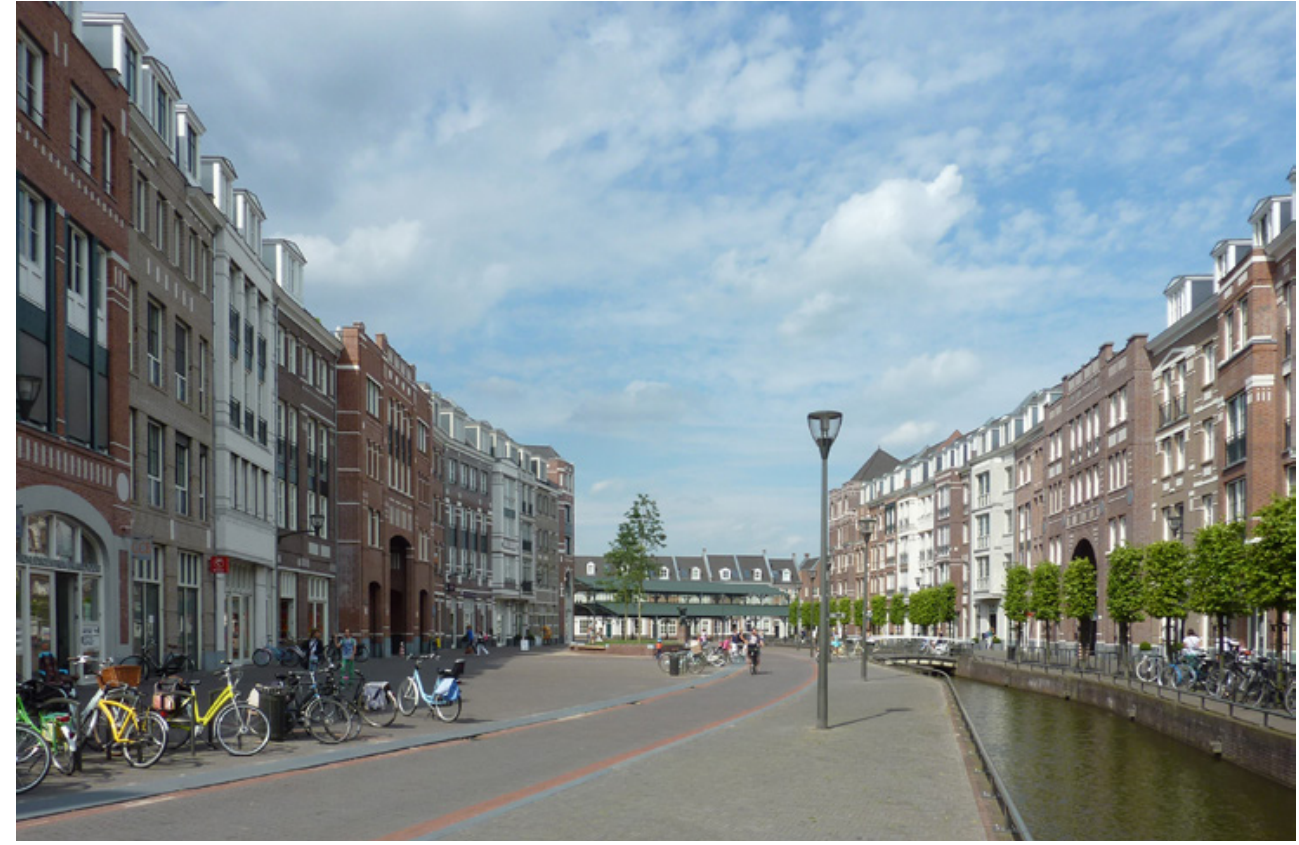

L.K.: Beauty and architecture are demanding - by nature and definition. With the exception of Dankward Guratzsch and Rainer Haubrich, the architecture critics in the German media are, without exception, either openly or covert modernists. For them, any modern traditional building belongs to the junk heap of history.

\section{M.S.: "Modern traditional” building?}

L.K.: Yes, because if the term modernity designates our time, era, generation it follows that traditional building activity of today is modern. Tradition and modernity are not contradictory. However traditional and modernist are. What most modernists simply do not grasp, is that democracy must ensure freedom of choice - also in matters of architecture and art.

M.S.: Good, but again: What does architecture look like that is beautiful and traditional, but at the same time not only reproduces earlier epochs, but is contemporary and expresses our epoch?

L.K.: When you build and design today, you can't help but express our time for better or for worse. Time expression is neither a quality nor an obligation, but an inescapable fact.
Brandevoort, Helmond, masterplan by Robert Krier and Christoph Kohl, 1997 onwards (Alejandro García Hermida)
1: Città Nuova, 19972 : View of an urban scene of Herencia de Allende, San Miguel de Allende, 2018 onwards
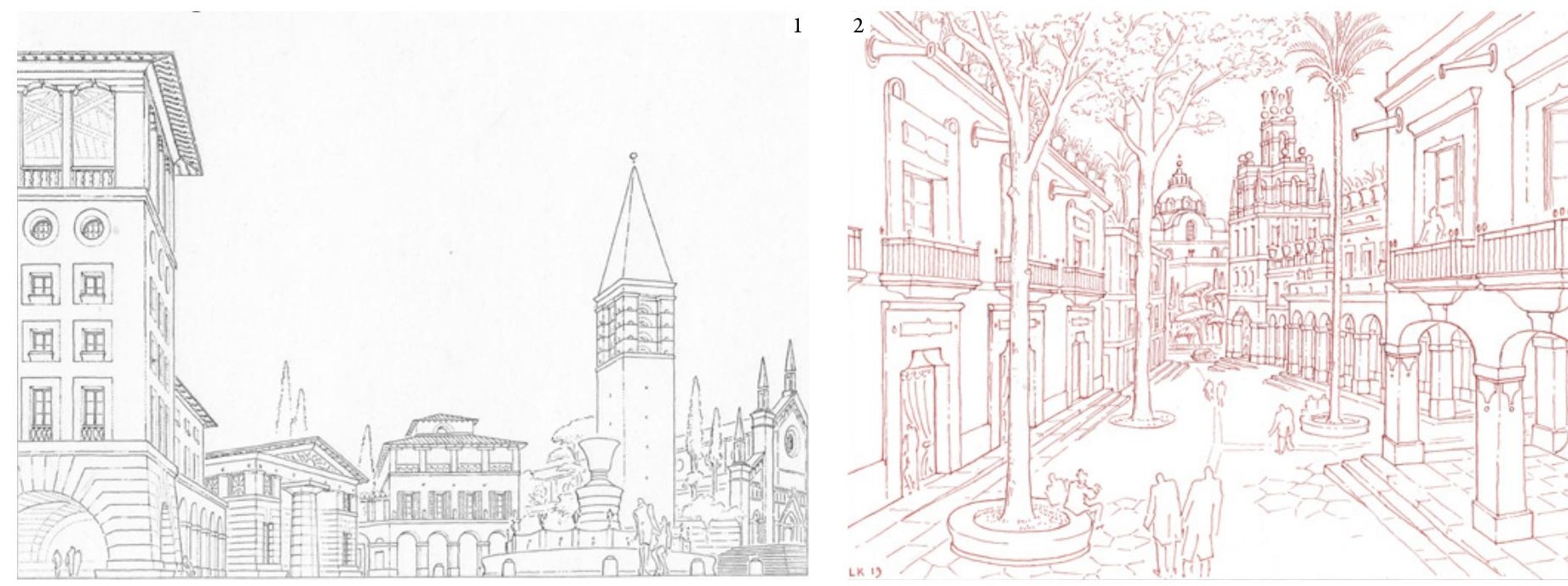
M.S.: Your example settlement of Poundbury in Cornwall, UK, with 3,500 inhabitants, realized together with Prince Charles, is world famous. However, this village-like, small-town complex is not a solution for our ever-growing cities - and also not for large buildings as many office buildings, company headquarters, shopping centres or residential buildings require nowadays because of the large number of users. Such complexes require massive structures and cannot be realized in the small-scale Poundbury style.

L.K.: Poundbury is a small-town project that doesn't pretend to be a solution for metropoles. However, people in large cities have the same physical measurements and abilities as in villages and small towns. That is why a quartier in Paris is no bigger than a quarter in Poundbury. According to traditional urban planning, the city should be articulated in a number of walkable urban quarters and walkable building heights. Each quarter should have a degree of self-sufficiency and therefore allow mixed use, mixed income and never be gated. In Poundbury, 35 percent of houses and apartments are "social," which means affordable for young families and low-wage earners. These "social houses" are not concentrated in one zone, but are pepper potted throughout the quarter.

They are externally indistinguishable from the buildings of their wealthier neighbours. Incidentally, that doesn't need to be planned, it just has to be allowed and not prohibited - that is common sense. My Cayala project in Guatemala, on the other hand, partly has a population density that corresponds to that of the City of London. It is simply wrong to think that "large buildings" and "compact structures" are inevitably condemned to the modernist forms canon. Gigantic buildings are usually formed from a typological dough that can be divided into several loaves of bread. Most of the so-called large buildings result from planning habits, not from the use - that is, they may be intentional but not necessary. In Luxembourg, together with my brother Rob Krier, I divided the new Palace of Justice into seven different buildings that are functionally independent. This facilitates use and orientation. Each building is easy to identify and the juvenile court cannot be confused with the high court or the library. The handy buildings do not face you like an elephantine block that gates off a part of town but line squares, alleys and promenades that integrate seamlessly into the old town street network. The news media ran up against it for years so deviously that the citizens apologize for liking it, uttering sub voce... "but then I am not an expert".

M.S.: Isn't the problem of architecture today, indeed of art in general, actually the phenomenon of "massification"? In times of mass historicism, i.e. in the 19th century, functionalism and Bauhaus were a boon because they were clear, pure and reductionist - a recovery from overloaded pomp. And today, in times of modern, functional building, the opposite, precisely minute detail and decoration, is perceived as a recovery from functional sobriety. In short: no matter how we build - will we not always long for the exact opposite because of the massification with which the respective style confronts us due to the size of our cities?
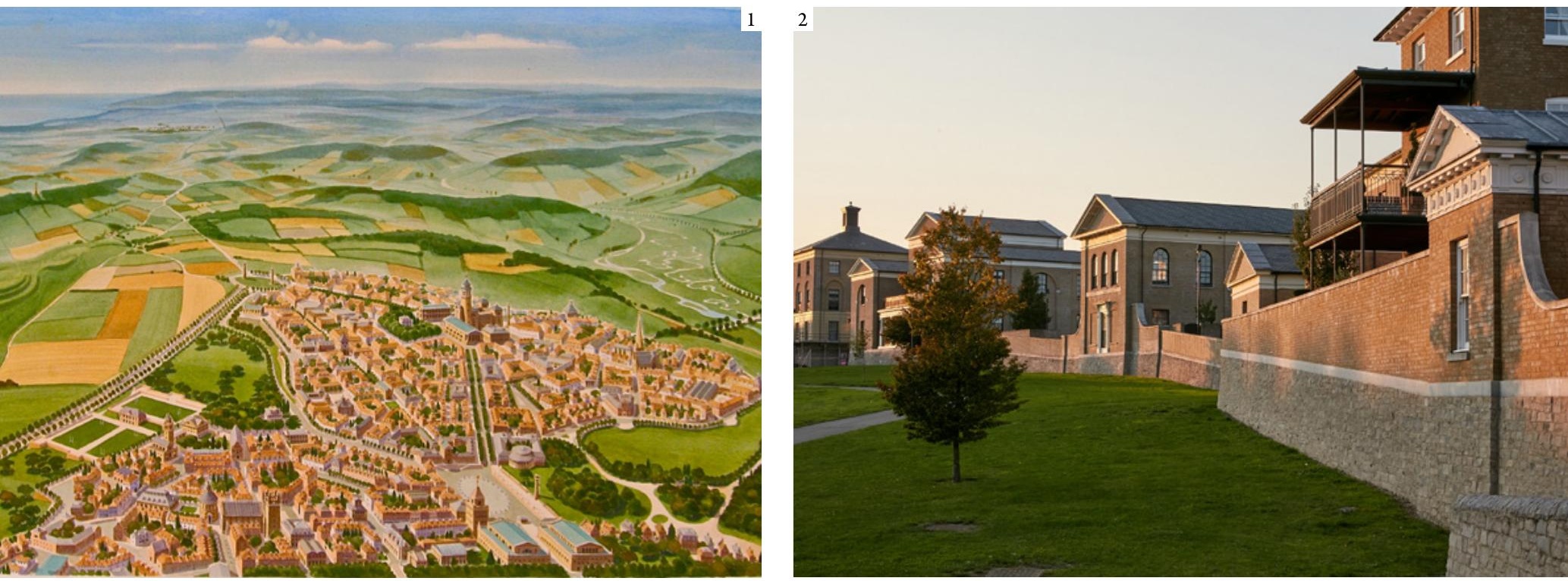
L.K.: Demetri Porphyrios Buildings for the University of Swansea in Wales and Robert A.M. Stern's Benjamin Franklin College and Pauli Murray College at Yale University, are state-of-the-art large-scale facilities in the classic style and are therefore very popular. Stern has over three hundred employees who have built modern, large-scale systems of all types and uses worldwide. There are also classic solutions for every use. The problem with Victorian eclecticism was that it tended towards a simultaneous uniformity and confusion of construction tasks, disguising factories as castles and pumping stations as mosques. The "Modern Movement", on the other hand, overreacts and creates cultural palaces that look like factories, mass dwellings like rabbit pens and schools that cannot be distinguished from prisons, churches or multi-level parking facilities. The typology of traditional building ranges from the telephone booth to the house, the department store, the warehouse, the cooling tower and airport. The difference to "Modernism" lies in the legibility and namability of types, forms and character and ultimately in their transgenerational usefulness and attractiveness. The beauty of a warehouse is of a different nature than that of a church, and that of a house is not to be confused with a temple or an aeroplane.

There is no future for a building industry that plans and builds short-lived consumer objects designed according to ever more short-lived fashions.

\section{Biographies | Biografías | Biografias}

\section{Leon Krier}

He is an Architecture and Urbanism consultant and a designer; author and teacher. He was born in 1946 in Luxembourg City. He studied at Stuttgart University from 1967 to 68 and left to work with James Stirling from 1968 to 1974. Leon Krier is a theorist who promotes the technological, ecological and social rationality and the modernity of traditional urbanism and architecture, summarized in his book The Architecture of Community (Island Press, 2009) and its expanded Spanish edition La arquitectura de la comunidad: La modernidad tradicional y la ecología del urbanismo (Editorial Reverté, 2013). Since 1988, he masterplans the New Town of Poundbury for The Prince of Wales; since 2003, Cayalá, in Guatemala; since 2015 and 2020 the El Socorro and the Nogales developments, also in Guatemala; and since 2018 the New Town of Herencia de Allende, in Guanajuato, México. He has taught a several schools of architecture and is a Visiting Professor at Yale School of Architecture and was awarded the British honour of Commander of the Royal Victorian Order, the Silver Medal of the Académie Française in 1997, the Athena Award of the Congress of New Urbanism in 2006 and was the inaugural recipient of the Richard H. Driehaus Prize in 2003. Since 1990 he also designs for Giorgetti and Valli-Valli.

\section{Moritz Schwarz}

He is an editor of the German weekly Junge Freiheit newspaper on politics and cultural affairs from Berlin. He was born 1971 in Heilbronn am Neckar, southwest Germany, and has studied Politics and History at Stuttgart University.
Paseo Cayalá, Guatemala City, 2003 onwards

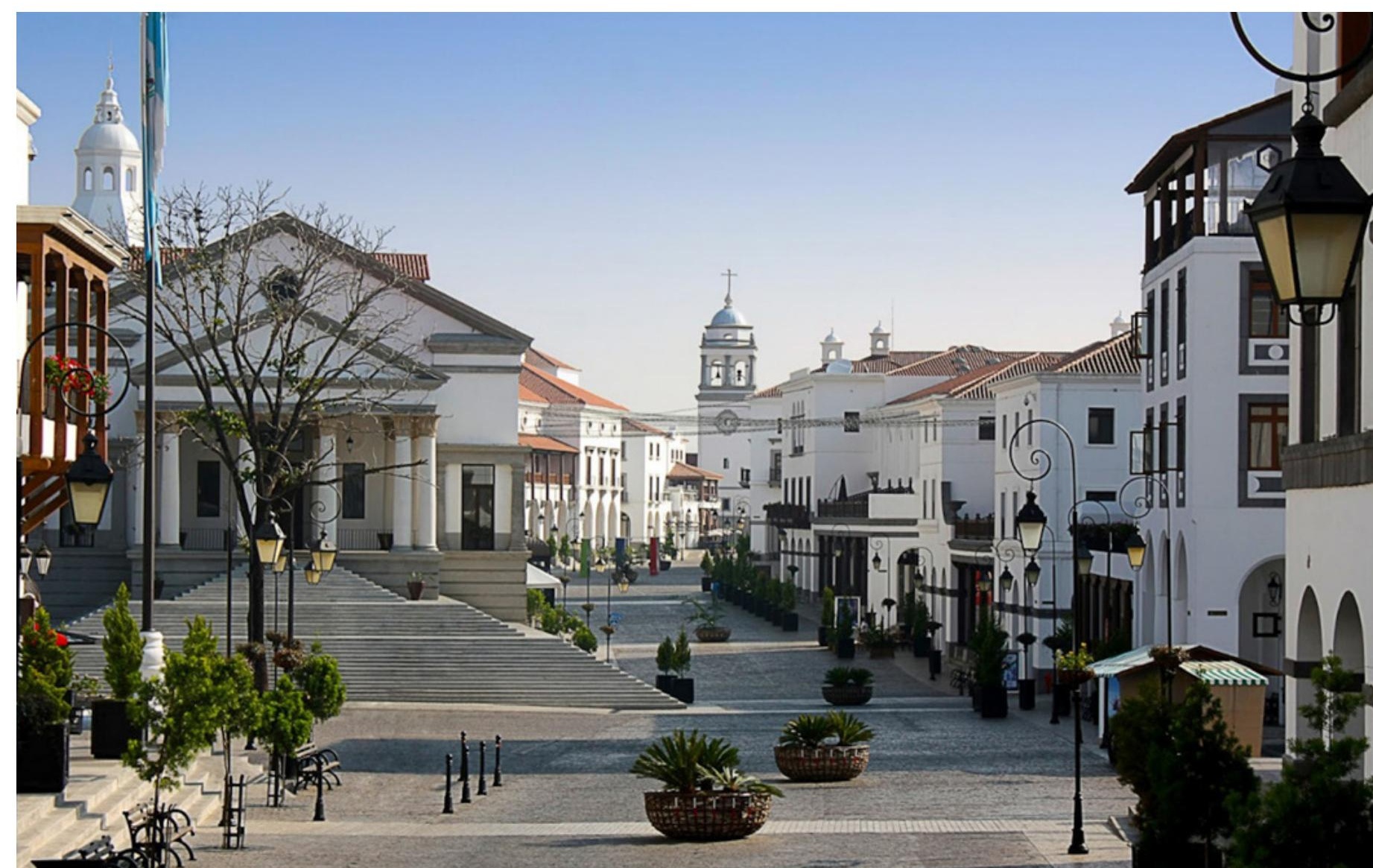

